\title{
EFFECT OF FABA BEAN AND CHICKPEA MUCILAGE INCORPORATION IN THE STRUCTURE AND FUNCTIONALITY OF KEFIR
}

\author{
Linda Ould Saadi, ${ }^{\text {ab }}$ Farid Zaidi ${ }^{\mathrm{b}}$, Teresa Sanz ${ }^{\mathrm{a}}$ and Claudia M.Haros ${ }^{{ }^{\mathrm{a}}}$
}

\footnotetext{
${ }^{\text {a } I n s t i t u t e ~ o f ~ A g r o c h e m i s t r y ~ a n d ~ F o o d ~ T e c h n o l o g y ~(I A T A-C S I C), ~ V a l e n c i a, ~ S p a i n ~}$

${ }^{\mathrm{b}}$ Departement des Sciences Alimentaires, Faculté des Sciences de la Nature et de la Vie, Université de Bejaia, Bejaia-Algeria
}

*Corresponding author: Claudia M. Haros, Institute of Agrochemistry and Food Technology (IATA). Spanish Council for Scientific Research (CSIC) Av. Agustín Escardino, 7 - Parque Científico 46980 - Paterna, Valencia - Spain

E-mail: cmharos@iata.csic.es 


\begin{abstract}
This investigation aimed to investigate the viability of kefir enrichment with mucilage extracted from faba bean and chickpea. Four formulations of kefir were studied: fermented milk (control); milk with $3 \%$ of faba bean mucilage, milk with $3 \%$ of chickpea mucilage and milk with $3 \%$ of inulin from artichoke (as prebiotic control). Kefirs were evaluated during 28 days storage time at refrigerated temperature. Microbial viability, physico-chemical properties (total titratable acidity, syneresis and $\mathrm{pH}$ ), rheological properties (flow and dynamic shear rheology) and consumer's acceptability were evaluated. The number of bacteria significantly increased during storage period in all formulations. The $\mathrm{pH}$ decreases during storage whereas total titratable acidity increased as was expected. Kefir supplemented with mucilage showed slightly lower but not significantly different sensory acceptability scores in comparison to the control. The novel mucilage ingredients could be prebiotic source for improving kefir quality.
\end{abstract}

KEYWORDS: Kefir, legumes, mucilage, rheology, sensory test 


\section{INTRODUCTION}

2 Kefir is a traditional beverage originated from Western and Central Asia obtained by

3 fermentation of milk using kefir grains. It was part of the diet of people from Europe and

4 America, but recently, it is getting popularity around the world. kefir grain have a complex

5 and variable microbiological composition including lactobacilli (Lactobacillus brevis,

6 Lactobacillus acidophilus, Lactobacillus casei, Lactobacillus lactis, Lactobacillus bulgaricus

7 and Lactobacillus plantarum), which represent the largest portion (65-80\%), lactococci

8 (Lactococcus lactis, Streptococcus thermophilus, Leuconostoc mesenteroides and

9 Lactococcus cremoris) and yeasts (Kluyveromyces, Candida and Saccharomyces) (Farnworth,

10 2003).

11 Similarly, to other dairy products, the enrichment of kefir with functional and nutritious

12 ingredients is a topic of recent interest. A noteworthy trend in recent times is the addition of prebiotics for the improvement of the nutritional properties of fermented dairy products.

Several studies involving the addition of prebiotic ingredients to dairy products have reported

15 a positive effect, both on the growth of probiotic bacteria and on the sensory, rheological and

16 physicochemical properties (Cruz et al., 2013; Oliveira et al., 2009).

17 There is great economic interest in finding new prebiotic-rich food matrices. Some plant18 based matrices are good source of prebiotic compounds like inulin-containing chicory. 19 Published data suggest that probiotic grow better in milk supplemented with legumes flour, 20 thus suggesting a prebiotic potential. Lentil flour supplementation (1-3\%) stimulated the 21 growth of yoghurt strains with marginal $\mathrm{pH}$ change during 28 days storage (Zare et al., 2011). 22 Lentil flour was superior to soy and other pulse ingredients (pea protein, pea fibre, chickpea 23 flour and soy protein) in improving probiotic Lactobacilli growth in yoghurt (Zare et al., 24 2012). Also green lentil flour (4\%) supplementation increased microbial growth selectively 25 for yoghurts containing Lb.acidophilus and B. lactis during storage for 28 days (Agil and 
Hosseinian, 2012). Faba bean flour supplementation (4\%) stimulated bifidogenic microbial growth, increased titratable acidity and reduced $\mathrm{pH}$ during kefir storage (Boudjou et al., 2014).

Légumes appear to be a good source of dietary fibre, mucilage is a complex carbohydrate, that constitue a part of the dietary fiber (Motiwala et al., 2015; Sáenz et al., 2004) . Literature survey reveals that mucilage is used as a good source of prebiotic, enhancing lactic acid bacteria growth in kefir model (HadiNezhad et al., 2013; Saadi et al., 2017).

To the best of our knowledge, there is no information available about the effects of mucilage from legumes seeds addition on the rheological properties and sensory acceptability of dairy products.

This study aimed to evaluate the effect of mucilage incorporation from Faba bean minor and Chickpea mucilage in kefir. The effect on total bacteria count, physicochemical and rheological properties during 4 weeks of cold storage was investigated. Furthermore, the kefir consumer's acceptability was evaluated.

\section{MATERIALS AND METHODS}

\section{Sample preparation}

Legume samples consisting of faba bean (Vicia faba L.) minor and chickpea (Ciser arietinum) were from Skikda-Algeria and Bejaia-Algeria, respectively. Samples were cleaned, air dried, initially crushed in a traditional stone mill followed by an electric mill (Moulinex, France) then sieved (Tap sieve shaker AS200; Retsch GmbH, Haan, Germany) to pass a $500 \mu \mathrm{m}$ screen. The powders were stored in refrigeration in sealed plastic bags until use.

\section{Extraction of Crude Mucilage}


It was followed the method described by HadiNezhad et al., (2013) ground chickpea and faba bean were extracted with distilled water $\left(10: 400\right.$, w/v), stirred for $3 \mathrm{~h}$ at $60{ }^{\circ} \mathrm{C}$. The extracts were allowed to cold at room temperature and then centrifuged with a Sorvall Legend XTR centrifuge (Thermo Scientific, Ashville, NC, USA) at $4000 \mathrm{~g}$ for $20 \mathrm{~min}$. Consequently, the supernatant was freeze-dried and the obtained fraction corresponded to the crude mucilage.

\section{Preparation and Characteristics of Kefir}

Kefir preparation was done according to the methodology described by Saadi et al., (2017). Four formulations were investigated: kefir with raw mucilage of faba bean minor (MWF), mucilage of chickpea (MCP), inulin of artichoc (IN) (at $3 \%$ ), and a control without fiber. The $\mathrm{pH}$, total tritratable acidity (TTA), bacteria count in MRS agar at $37^{\circ} \mathrm{C}$ during $24 \mathrm{~h}$ (Saadi et al., 2017). Syneresis index of different kefir samples was determined according to the methodology described by Han et al., (2016) with modifications. Kefir (5 g) was prepared in centrifuge cups and centrifuged at $4000 \mathrm{~g}$ (Thermo Electron Led GmbH D-27520 osterode, Germany) for $10 \mathrm{~min}$ at $4^{\circ} \mathrm{C}$. The clear supernatant was collected and weighed, the syneresis was calculated according to the following the Eq. 1:

Syneresis $(\%)=($ Weight of supernatant $(\mathrm{g}) /$ weight of kefir sample $(\mathrm{g})) \times 100$

(Eq. 1)

The color of kefir samples was measured by reflectance in spectrocolorimeter (Konica Minolta CM-3500) at 1, 7, 14, 21 and 28 days of storage by introduce them in a measurement window cap. Results were expressed in accordance with the CIELAB system using the illuminant D65 and $10^{\circ}$ viewing angle. The parameters measured were $\mathrm{L}^{*}\left(\mathrm{~L}^{*}=0\right.$ [black], $\mathrm{L}^{*}=100$ [white], $\mathrm{a}^{*}\left(+\mathrm{a}^{*}=\mathrm{red}\right)$ and $\mathrm{b}^{*}\left(+\mathrm{b}^{*}=\right.$ yellow $)$. For each formula measurements were carried out in three different batches, and four measurements were carried out in each batch.

\section{Rheological analysis}


The rheological analyses were carried out on days 1, 7, 14, 21 and 28 of refrigerated storage at $4^{\circ} \mathrm{C}$ by a control stress rheometer (ARG2TA Instruments). Stainless steel serrated plate geometry with $40 \mathrm{~mm}$ of diameter and $1 \mathrm{~mm}$ gap was employed. Rheological measurements were carried out at $20.0^{\circ} \mathrm{C}$. Time dependence behavior was studied by the hysteresis loop method. Shear stress was determined at shear rates between 1 and $100 \mathrm{~s}^{-1}$ in (up curve) and from $100 \mathrm{~s}^{-1}$ to $1 \mathrm{~s}^{-1}$ (down curve). Areas under the upstream data points (Aup) and under the downstream data points (Adown) as well as the Relative hysteresis area ((Aup-Adown)/Aup) x 100 were calculated. Shear stress versus shear rate in the up curve were adjusted to the power law model (Eq. 1)

$$
\sigma=k y^{n} \quad(\text { Eq. } 2)
$$

Where $\sigma$ is the shear stress $(\mathrm{Pa}), k$ is the consistency index $\left(\mathrm{Pa} \mathrm{s}^{\mathrm{n}}\right), \dot{y}$ the shear rate $\left(\mathrm{s}^{-1}\right)$, and $n$ the flow behavior index (dimensionless).

Oscillatory shear experiments were carried out at a maximum strain of $1 \%$ and the frequency varied between 10 and $0.01 \mathrm{~Hz}$. The storage moduli (G'), loss moduli (G”) moduli and loss tangent $(\tan \delta)$, were determined. Before measurement the samples were always kept at room temperature for around $20 \mathrm{~min}$, sample syneresis was removed and the samples were mixed softly with a spatula. All trials were carried out in triplicate.

\section{Sensory test}

Sensory test was carried out in a standardised test room (ISO, 2007). A total of 65 consumers recruited from IATA staff was employed. Samples were prepared the day before the test and were served $(\sim 15 \mathrm{ml})$ at refrigerated temperature in white plastic cups codified with three digit-numbers. Mineral water was served to consumers for cleaning their mouths. Samples were presented monodically to consumers following a Williams design for three samples (Macfie \& Bratchell, 1989; Sahan, Yasar, \& Hayaloglu, 2008; Macfie \& Bratchell, 1989). 
The consumers evaluated the odour, flavour, texture and overall acceptability of each sample

101 using a 9-point hedonic scale ranging from 1 ("dislike extremely") to 9 ("like extremely"). The purchase intention of each sample was evaluated using a 5-point scale from 1 ("definitely would not buy") to 5 (“definitely would buy”).

\section{Statistical analysis}

106 Statistical analyses were carried out with the software Statgraphics Plus 7.1 (Bitstream, 107 Cambridge, $\mathrm{Mn}$ ), and differences were considered significant at $p<0.05$.

108 For the sensory test, the data acquisition and statistical analysis were performed using 109 Compusense five release 5.0 software (Compusense Inc., Guelph, Ontario, Canada).

\section{RESULTS AND DISCUSSION}

\section{Physicochemical and microbiological analysis}

113 The evolution of total bacteria $(\log \mathrm{CFU} / \mathrm{mL})$ during kefir storage at days 1, 7, 14, 21 and 28

114 is shown in Table 1. All kefir samples showed marked increase in the total bacteria count on 115 the day 7 compared to day 1 . After day 7, the count remained constant until day 21 and 116 decreased thereafter. Titratable acidity of kefir varied depending on storage time and 117 supplementation (Table 1). K+MWF and $\mathrm{K}+\mathrm{MCP}$ provided the greatest increase in the 118 acidity between the 14 and 21 days of refrigerated storage around $16 \%$ and $10 \%$ respectively.

119 Statistically significant $(p<0.05)$ differences were found in TTA content between 1 and 28120 day storage for all kefir samples.

121 In all the kefir samples studied $\mathrm{pH}$ decrease with storage time (Table 1). After 28 days' 122 storage, $\mathrm{K}+\mathrm{IN}$ had the lowest $\mathrm{pH}$, followed by those supplemented with $\mathrm{K}+\mathrm{MCP}$ and $123 \mathrm{~K}+\mathrm{MWF}$. Similar results on the evolution of bacteria count, the TTA increment and $\mathrm{pH}$ 124 decreasement during kefir storage were reported in recent works in kefir supplemented with 
125 faba bean flour, inulin, chickpea mucilage and flaxseed mucilage (Boudjou et al., 2014;

126 HadiNezhad et al., 2013; Saadi et al., 2017). At the last day of cold storage (day 28), the

127 number of total bacteria in kefir samples range from 7.4 to $8.16 \log \mathrm{CFU} / \mathrm{mL}$, which is upper

128 the minimum recommended level of $7 \log \mathrm{CFU} / \mathrm{mL}$ defined by the legislation during cold

129 storage (Cruz et al., 2013; Purwandari et al., 2007).

130 Syneresis. At day 1 of storage all supplemented kefirs showed higher syneresis than the

131 control (Table 1). Kefir supplemented with chickpea mucilage showed the highest percentage

132 of syneresis followed by faba bean mucilage and inulin.

133 The control kefir showed a significant increase in syneresis with storage time, as was

134 previously observed by Aryana and Mcgrew, (2007). The authors described that post

135 acidification and reduction of $\mathrm{pH}$ in fermented milk causes the contraction of the casein

136 micelles, which in turn results in a firmer and more cohesive structure. Therefore, syneresis

137 was directly linked to acidification during storage.

138 On the contrary, in the supplemented kefir no increase in syneresis was observed during

139 storage. After 21 days storage time both the mucilage kefirs showed a decrease in syneresis.

140 After 28 days, the lowest significant syneresis value was found by the faba bean kefir. The

141 reduction in syneresis from day 1 to 21 may be associated to an increase in total solid

142 content, especially protein, starch, and fiber which have hydrocolloidal properties in the

143 supplemented kefirs, which confers a stronger and more homogenous texture (Lucey et al.,

144 2001). According to Brennan and Tudorica, (2008) ; Montanuci et al., (2012) higher

145 firmness makes fermented milk less susceptible to serum separation. Fibers, have been

146 reported to reduce syneresis in fermented milks during storage because of their high water

147 holding capacity (Aportela-Palacios et al., 2005; Guven et al., 2005).

148

149 Rheological properties 
Flow properties. Shear stress versus shear rate for the up and down curves are shown in

151 Figure 1. The increase in shear stress with the increase in shear rate reveals the shear thinning 152 behaviour of all the kefir samples. In all the shear rate range studied both mucilage kefir 153 showed the highest values of shear stress and the control kefir the lowest.

154 Values of shear stress versus shear rate corresponding to the up curve were satisfactorily 155 adjusted to the power law model for all formulations and storage time (values of $\mathrm{R}^{2}$ always 156 higher than 0.95). The values of the consistency $(\mathrm{K})$ and pseudoplastic index are shown in 157 Table 2. All kefirs were pseudoplastic fluids as evidenced by the flow behavior index $(\mathrm{n}<1)$. 158 At all storage times, the kefirs supplemented with mucilage had the highest consistency index $159(K)$, and the lowest flow behavior index (values of $\mathrm{n}$ closer to 0 ), which reflects a thicker 160 structure of the mucilage kefirs in comparison to inulin kefir and control. The thicker 161 structure of mucilage kefirs is explained due to the protein, starch and fiber present in the crude mucilage.

163 Over the shear rate range of $0.1-100 / \mathrm{s}$ the power law equation was also successfully applied to 164 study the flow properties of fermented milks (yoghurt) (Cruz et al., 2013; Debon et al., 2010; 165 Yu et al., 2016).

166 In the experimental conditions applied (shearing time and range of shear rates) all the sample 167 show hysteresis area. The hysteresis area among the up and down curves indicates that the 168 sample's flow is time dependent. The area between the up and down curves (hysteresis area) 169 is an index of the energy per unit time and unit volume needed to eliminate the influence of 170 time in flow behaviour. To compare the hysteresis areas among the different kefir samples the 171 parameter relative hysteresis was calculated, as comparison of straight loop areas between 172 differently viscous systems may not render valid conclusions on the extension of time173 dependent structural breakdown (Dolz et al., 2000). The relative hysteresis area for all the 174 kefir samples are shown in Table 3. The highest relative hysteresis area was found in both the 
mucilage kefir, whereas the inulin kefir showed the lowest hysteresis area, implying that the

176 energy required to break the structure was higher in the mucilage kefirs, which also indicates

177 the most complex structure provided by the crude mucilage.

178 Viscoelasticity: dynamic testing. The dynamic testing provides information on the

179 viscoelastic properties of kefirs. Figure 2a shows the dependence of the storage modulus $\left(\mathrm{G}^{\prime}\right)$

180 and the loss modulus (G") with frequency in the first day of storage. Figure $2 b$ shows the tan

$181 \delta$ versus frequency in the first day of storage. In Table 2 the values of G', G', and tan $\delta$ at 1

$182 \mathrm{~Hz}$ are shown. Similarly to yoghurt viscoelastic properties, the kefir reveal a weak gel 183 behavior with values of G' always higher than G' and a soft dependence with frequency

184 (Cruz et al., 2013; Yu et al., 2016).

185 The addition of inulin and mucilages influenced the viscoelastic behavior significantly $186(p<0.05)$. Independently of storage time, the values of G' and G" were higher in MCP (sample

187 with mucilage of chickpea), followed in decreasing order by MWF (sample with mucilage of 188 faba bean) and IN (sample with inulin), which showed significantly the lowest G' values. A 189 very small difference in viscoelasticity $\tan \delta\left(\mathrm{G}^{\prime \prime} / \mathrm{G}^{\prime}\right)$ was found among the different kefirs.

190 The lowest viscoeslasticity (values of $\tan \delta$ closer to 1 ) was found by the control kefir sample,

191 with no significant differences among the inulin and the mucilage kefirs.

192 The lowest $G^{\prime}$ and G', values of the inulin kefir agree with previous results found with the 193 addition of inulin to yoghurt samples. Paseephol et al., (2008) found a decrease in gel 194 strength in yoghurt supplemented with inulin at different levels (0.2-0.8\%). This trend was 195 explained by the fact that inulin formed aggregates with proteins in yoghurt through hydrogen 196 bonds playing as structure breaker, preventing the formation of the protein network (Chiavaro 197 et al., 2007).

198 The values of $G^{\prime}$ and G' in all the kefirs samples increase with the storage time $p<0.05$. In 199 fact other authors observed the same trend with yoghurt (Cruz et al., 2013; Donkor et al., 
2007; Vasiljevic et al., 2007). The effect was associated with the large number of protein

201 interactions and rearrangements occurring during storage (Ozer et al., 1997).

202 Colour. The effect of kefir supplementation and storage in the instrumental colour 203 parameters is shown in Table 3. On the first day of cold storage inulin and faba bean mucilage 204 supplemented samples had significantly lower lightness and higher $\mathrm{a}^{*}$ and $\mathrm{b}^{*}$ values 205 comparing to control and MCP sample. Colour parameters did not show differences along the 206 storage time, this behaviour was similar to that observed in yoghurts supplemented with 207 dietary fibre from apple, inulin and oligofructose (Aryana and Mcgrew, 2007; Staffolo et al., 208 2004). According to these authors, a factor that influences the colour of the product is the 209 colour of the ingredients used. The color measurements indicate that the inulin and faba bean 210 mucilage supplemented kefir had lower lightness, less greenness and more yellowness in 211 comparison with control kefir and chickpea mucilage ingredient.

212 Sensory test. Table 4 shows the results of sensory hedonic evaluation of the different kefirs 213 by a consumer panel. The supplemented kefir showed lower values of acceptability than the 214 control, although the differences found were small and no significantly different. No 215 significant $(p<0.05)$ differences in odour, texture, overall acceptability and purchase intention 216 among the control and the mucilage enriched kefir were found. These results indicate that mucilage supplementation of kefir will not alter significantly consumer acceptability of the product. Ertekin and Guzel-seydim, (2010) found that odour and taste scores of kefir samples with or without supplementation of inulin were no different.

\section{CONCLUSION}

222 This study was conducted to investigate the potential of faba bean minor and chickpea mucilages to boost the bacterial growth in a kefir system, followed by rheological behavior

224 during storage and sensory acceptability of the final product. In the rheological evaluation 
was observed an increase in viscoelasticity with storage time. Mucilage supplementation

226 increased the viscosity comparing to kefir control. Mucilage from chickpea and faba bean in

227 kefir resulted in a slight decrease of sensory acceptability but without significant differences

228 in odor and texture attributes. The results demonstrated that mucilages act as a good source of

229 complex carbohydrates, enhancing lactic-acid bacteria growth in kefir. Legume's mucilage as

230 food ingredient could also affect the probiotic functionality in human gut. Clinical 231 investigations to determine in vivo prebiotic and probiotic activity of mucilage's will be an 232 interesting future study.

\section{ACKNOWLEDGEMENTS}

235 This work was supported by grants QuiSalhis-Food AGL2016-75687-C2-1-R from Ministerio 236 de Ciencia, Innovación y Universidades (MICIU), la ValSe-Food-CYTED 119RT0567 from

237 Programa Iberoamericano de Ciencia y Tecnología para el Desarrollo, and LINCE 238 (PROMETEO/2017/189) from the Generalitat Valenciana, Spain. The internship grant of 239 Ph.D student Linda Ould Saadi from Abderrahmane Mira University, Bejaia-Algeria, is 240 gratefully acknowledged.

\section{REFERENCES}

Agil R and Hosseinian F (2012) Dual Functionality of Triticale as a Novel Dietary Source of Prebiotics with Antioxidant Activity in Fermented Dairy Products. Plant Foods for

Aportela-Palacios A, Sosa-Morales ME and Vélez-Ruiz JF (2005) Rheological and physicochemical behavior of fortified yogurt, with fiber and calcium. Journal of Texture Studies 36(3): 333-349. DOI: 10.1111/j.1745-4603.2005.00020.x. 
various prebiotics. LWT - Food Science and Technology 40 (10): 1808-1814. DOI: 10.1016/j.lwt.2007.01.008.

Boudjou S, Zaidi F, Hosseinian F, et al. (2014) Effects of Faba Bean (Vicia faba L.) Flour on Viability of Probiotic Bacteria During Kefir Storage. Journal of Food Research 3(6): 13. DOI: 10.5539/jfr.v3n6p13.

Brennan CS and Tudorica CM (2008) Carbohydrate-based fat replacers in the modification of the rheological, textural and sensory quality of yoghurt : comparative study of the utilisation of barley beta-glucan, guar gum and inulin. Internatinal Journal of Food Science Technology 43: 824-833. DOI: 10.1111/j.1365-2621.2007.01522.x.

Chiavaro E, Vittadini E and Corradini C (2007) Physicochemical characterization and stability of inulin gels. European Food Research and Technology 225(1): 85-94. DOI: 10.1007/s00217-006-0385-y.

Cruz AG, Cavalcanti RN, Guerreiro LMR, et al. (2013) Developing a prebiotic yogurt: Rheological, physico-chemical and microbiological aspects and adequacy of survival analysis methodology. Journal of Food Engineering 114(3) : 323-330. DOI: 10.1016/j.jfoodeng.2012.08.018.

Debon J, Prudêncio ES and Cunha Petrus JC (2010) Rheological and physico-chemical characterization of prebiotic microfiltered fermented milk. Journal of Food Engineering 99(2): 128-135. DOI: 10.1016/j.jfoodeng.2010.02.008.

Dolz M, Gonzlez F, Delegido J, et al. (2000) A time-dependent expression for thixotropic areas. Application to Aerosil 200 hydrogels. Journal of Pharmaceutical Sciences 89(6): 790-797. DOI: 10.1002/(SICI)1520-6017(200006)89:6<790::AID-JPS11>3.0.CO;2-2.

Donkor ON, Nilmini SLI, Stolic P, et al. (2007) Survival and activity of selected probiotic organisms in set-type yoghurt during cold storage. International Dairy Journal 17 (6): 657-665. DOI: 10.1016/j.idairyj.2006.08.006. 
275 Ertekin B and Guzel-seydim ZB (2010) Effect of fat replacers on kefir quality. Journal of the Science of Food and Agriculture 90 (4): 543-548. DOI: 10.1002/jsfa.3855.

277 Farnworth ER (2003) Kefir - a complex probiotic. Food Science \& Technology Bulletin Functional Foods 2(1) : 1-17. DOI: 10.1616/1476-2137.13938.

Guven M, Yasar K, Karaca OB, et al. (2005) The effect of inulin as a fat replacer on the quality of set-type low-fat yogurt manufacture. International Journal of Dairy Technology 58(3): 180-184. DOI: 10.1111/j.1471-0307.2005.00210.x.

HadiNezhad M, Duc C, Han NF, et al. (2013) Flaxseed Soluble Dietary Fibre Enhances Lactic Acid Bacterial Survival and Growth in Kefir and Possesses High Antioxidant Capacity. Journal of Food Research 2(5): 152-163. DOI: 10.5539/jfr.v2n5p152.

Han X, Yang Z, Jing X, et al. (2016) Improvement of the Texture of Yogurt by Use of Exopolysaccharide Producing Lactic Acid Bacteria. BioMed Research International 2016 :1-6 . DOI: 10.1155/2016/7945675.

Lucey JA, Tamehana M, Singh H, et al. (2001) Effect of heat treatment on the physical properties of milk gels made with both rennet and acid. International Dairy Journal

Montanuci FD, Pimentel TC, Garcia S, et al. (2012) Effect of starter culture and inulin addition on microbial viability, texture, and chemical characteristics of whole or skim milk Kefir. Food Science and Technology (Campinas) 32(4): 580-865. DOI:

Motiwala MN, Dumore MN, Rokde V V., et al. (2015) Characterization and antioxidant potential of Coccinia indica fruit mucilage: Evaluation of its binding properties. Bioactive Carbohydrates and Dietary Fibre 6(2): 69-74. DOI: 10.1016/j.bcdf.2015.09.001.

Oliveira RPS, Florence ACR, Silva RC, et al. (2009) Effect of different prebiotics on the 
fermentation kinetics, probiotic survival and fatty acids profiles in nonfat symbiotic fermented milk. International Journal of Food Microbiology 128(3): 467-472. DOI: 10.1016/j.ijfoodmicro.2008.10.012.

303

304

Ozer BH, Robinson RK, Grandison AS, et al. (1997) Comparison of techniques for measuring the rheological properties of labneh (concentrated yogurt). International Journal of Dairy Technology 50(4): 129-133. DOI: 10.1111/j.1471-0307.1997.tb01753.x.

Paseephol T, Small DM and Sherkat F (2008) Rheology and Texture of Set Yogurt As Affected By Inulin Addition. Journal of Texture Studies 39(6): 617-634. DOI: 10.1111/j.1745-4603.2008.00161.x.

Purwandari U, Shah NP and Vasiljevic T (2007) Effects of exopolysaccharide-producing strains of Streptococcus thermophilus on technological and rheological properties of settype yoghurt. International Dairy Journal 17(11): 1344-1352. DOI: 10.1016/j.idairyj.2007.01.018.

Saadi LO, Zaidi F, Oomah BD, et al. (2017) Pulse ingredients supplementation affects kefir quality and antioxidant capacity during storage. LWT - Food Science and Technology 86: 619-626. DOI: 10.1016/j.lwt.2017.08.011.

Sáenz C, Sepúlveda E and Matsuhiro B (2004) Opuntia spp. mucilage’s: A functional component with industrial perspectives. Journal of Arid Environments 57(3): 275-290. DOI: 10.1016/S0140-1963(03)00106-X.

Staffolo M Dello, Bertola N, Martino M, et al. (2004) Influence of dietary fiber addition on sensory and rheological properties of yogurt. International Dairy Journal 14 (3): 263268. DOI: 10.1016/j.idairyj.2003.08.004.

Tarancón P, Sanz T, Salvador A, et al. (2014) Effect of Fat on Mechanical and Acoustical Properties of Biscuits Related to Texture Properties Perceived by Consumers. Food and Bioprocess Technology 7(6): 1725-1735. DOI: 10.1007/s 11947-013-1155-z. 
325 Vasiljevic T, Kealy T and Mishra VK (2007) Effects of -glucan addition to a probiotic containing yogurt. Journal of Food Science 72(7): 405-411. DOI: 10.1111/j.17503841.2007.00454.x.

328 Yu H, Wang L and Mccarthy KL (2016) Characterization of yogurts made with milk solids nonfat by rheological behavior and nuclear magnetic resonance spectroscopy. Journal of Food and Drug Analysis 24(4): 804-812. DOI: 10.1016/j.jfda.2016.04.002.

331 Zare F, Boye JI, Orsat V, et al. (2011) Microbial, physical and sensory properties of yogurt supplemented with lentil fl our. Food Research International 44(8): 2482-2488. DOI: 10.1016/j.foodres.2011.01.002.

334 Zare F, Champagne CP, Simpson BK, et al. (2012) Effect of the addition of pulse ingredients to milk on acid production by probiotic and yoghurt starter cultures. LWT - Food Science and Technology 45(2): 155-160. DOI: 10.1016/j.lwt.2011.08.012. 


\section{$338 \quad$ Figure captions}

340 Fig 1. Flow curves of Kefir samples in the first day of storage. Control Kefir (K), Kefir

341 supplemented with faba bean mucilage (K+MWF), with chickpea mucilage $(\mathrm{K}+\mathrm{MCP})$ and 342 with inulin $(\mathrm{K}+\mathrm{IN})$.

343

344 Fig 2.a Storage modulus (G') and loss modulus (G') versus frequency in the first day of 345 storage. Control Kefir (K), Kefir with faba bean mucilage (K+MWF), chickpea mucilage $346(\mathrm{~K}+\mathrm{MCP})$ and inulin $(\mathrm{K}+\mathrm{IN})$.

348 Fig 2.b Tan $\delta$ versus frequency in the first day of storage. Control Kefir (K), Kefir with faba 349 bean mucilage $(\mathrm{K}+\mathrm{MWF})$, chickpea mucilage $(\mathrm{K}+\mathrm{MCP})$ and inulin $(\mathrm{K}+\mathrm{IN})$. 
351 Table 1. Effect of storage on the characteristic of kefir ${ }^{a b}$

\begin{tabular}{|c|c|c|c|c|c|c|}
\hline \multirow[t]{2}{*}{ Parameter } & \multirow[t]{2}{*}{ Units } & \multirow[t]{2}{*}{ Days } & \multicolumn{4}{|c|}{ Kefir samples } \\
\hline & & & $\mathrm{K}$ & $\mathrm{K}+\mathrm{IN}$ & $\mathrm{K}+\mathrm{MCP}$ & K+MWF \\
\hline \multirow{5}{*}{$\begin{array}{l}\text { Bacterial } \\
\text { enumeration }\end{array}$} & \multirow{5}{*}{$\begin{array}{l}\mathrm{Log} \\
\mathrm{UFC} / \mathrm{ml}\end{array}$} & 1 & $7.46 \pm 0.05 \mathrm{aA}$ & $7.65 \pm 0.07 \mathrm{aA}$ & $7.78 \pm 0.01 \mathrm{aB}$ & $7.82 \pm 0.01 \mathrm{aC}$ \\
\hline & & 7 & $7.57 \pm 0.02 \mathrm{bA}$ & $8.25 \pm 0.02 \mathrm{bB}$ & $9.06 \pm 0.4 \mathrm{cC}$ & $9.36 \pm 0.04 \mathrm{eD}$ \\
\hline & & 14 & $7.71 \pm 0.04 \mathrm{cA}$ & $8.40 \pm 0.05 \mathrm{cB}$ & $9.0 \pm 0.2 \mathrm{cC}$ & $9.1 \pm 0.2 \mathrm{dD}$ \\
\hline & & 21 & $7.6 \pm 0.1 \mathrm{bcA}$ & $8.22 \pm 0.03 \mathrm{bcB}$ & $8.2 \pm 0.3 \mathrm{bC}$ & $8.31 \pm 0.09 \mathrm{cD}$ \\
\hline & & 28 & $7.4 \pm 0.1 \mathrm{aA}$ & $7.8 \pm 0.1 \mathrm{~dB}$ & $8.16 \pm 0.09 \mathrm{bC}$ & $7.94 \pm 0.09 \mathrm{bD}$ \\
\hline \multirow{5}{*}{$\mathrm{pH}$} & & 1 & $4.3 \pm 0.2 \mathrm{cA}$ & $4.31 \pm 0.03 \mathrm{cdB}$ & $4.2 \pm 0.1 \mathrm{cC}$ & $4.33 \pm 0.01 \mathrm{dC}$ \\
\hline & & 7 & $4.23 \pm 0.05 \mathrm{cA}$ & $4.12 \pm 0.05 \mathrm{cB}$ & $4.22 \pm 0.01 \mathrm{cC}$ & $4.23 \pm 0.04 \mathrm{cB}$ \\
\hline & & 14 & $3.96 \pm 0.05 \mathrm{bB}$ & $3.78 \pm 0.02 \mathrm{bA}$ & $3.76 \pm 0.05 \mathrm{bcC}$ & $4.06 \pm 0.05 \mathrm{bcC}$ \\
\hline & & 21 & $4.03 \pm 0.02 \mathrm{bB}$ & $3.80 \pm 0.05 \mathrm{bA}$ & $3.4 \pm 0.1 \mathrm{bC}$ & $3.9 \pm 0.1 \mathrm{bCD}$ \\
\hline & & 28 & $3.80 \pm 0.01 \mathrm{aB}$ & $3.03 \pm 0.05 \mathrm{aA}$ & $3.2 \pm 0.1 \mathrm{aC}$ & $3.51 \pm 0.02 \mathrm{aC}$ \\
\hline \multirow{5}{*}{ TTA } & \multirow{5}{*}{$\%$} & 1 & $0.73 \pm 0.02 \mathrm{aB}$ & $0.81 \pm 0.01 \mathrm{bA}$ & $0.58 \pm 0.04 \mathrm{aC}$ & $0.76 \pm 0.04 \mathrm{aCD}$ \\
\hline & & 7 & $0.79 \pm 0.02 \mathrm{bB}$ & $0.63 \pm 0.01 \mathrm{aA}$ & $0.64 \pm 0.02 \mathrm{bC}$ & $0.79 \pm 0.02 \mathrm{aC}$ \\
\hline & & 14 & $0.76 \pm 0.04 \mathrm{ab} \mathrm{AB}$ & $0.87 \pm 0.05 \mathrm{cA}$ & $0.72 \pm 0.01 \mathrm{cB}$ & $0.82 \pm 0.04 \mathrm{bBC}$ \\
\hline & & 21 & $0.79 \pm 0.07 \mathrm{bB}$ & $0.84 \pm 0.05 \mathrm{bcA}$ & $0.83 \pm 0.07 \mathrm{dC}$ & $0.9 \pm 0.09 \mathrm{cD}$ \\
\hline & & 28 & $0.81 \pm 0.08 \mathrm{cB}$ & $0.90 \pm 0.01 \mathrm{dAB}$ & $0.94 \pm 0.04 \mathrm{eD}$ & $0.87 \pm 0.05 \mathrm{bcCD}$ \\
\hline \multirow{5}{*}{ Syneresis } & \multirow{5}{*}{$\%$} & 1 & $70.7 \pm 1.2 \mathrm{bB}$ & $73.7 \pm 0.8 \mathrm{dA}$ & $72.5 \pm 0.1 \mathrm{cC}$ & $74.1 \pm 2.1 \mathrm{eD}$ \\
\hline & & 7 & $68.9 \pm 0.2 \mathrm{aB}$ & $71.3 \pm 1.6 \mathrm{cA}$ & $69.2 \pm 0.3 \mathrm{abC}$ & $72.4 \pm 1.7 \mathrm{dC}$ \\
\hline & & 14 & $70.7 \pm 0.2 \mathrm{bB}$ & $68.9 \pm 0.1 \mathrm{abA}$ & $68.7 \pm 0.6 \mathrm{aC}$ & $68 \pm 2.7 \mathrm{aC}$ \\
\hline & & 21 & $72.7 \pm 0.8 \mathrm{cB}$ & $66.7 \pm 0.7 \mathrm{aA}$ & $71.3 \pm 0.8 \mathrm{cBC}$ & $69.1 \pm 1.0 \mathrm{abBC}$ \\
\hline & & 28 & $75.0 \pm 0.2 \mathrm{~dB}$ & $71.3 \pm 0.5 \mathrm{cAB}$ & $78.4 \pm 0.3 \mathrm{dC}$ & $70.8 \pm 0.6 \mathrm{cC}$ \\
\hline
\end{tabular}

353

354

${ }^{\mathrm{a}}$ Means $\pm \mathrm{SD}, \mathrm{n}=3$, the values of the same column by parameter with different tiny letters are significantly different and the values in the same row with different capital letters are significantly different $(\mathrm{P}<0.05)$. ${ }^{\mathrm{b}} \mathrm{K}$, Control kefir; $\mathrm{K}+\mathrm{MWF}$, kefir with mucilage of faba bean; $\mathrm{K}+\mathrm{MCP}$, kefir with chickpea mucilage, $\mathrm{K}+\mathrm{IN}$, and kefir with inulin, storage at $4{ }^{\circ} \mathrm{C}$ during 28 days; UFC: Unit forming colonies; TTA: Total Titrable Acidity \%. 
Table 2. Storage modulus (G'), loss modulus (G”), loss angle ( $\operatorname{Tg} \delta$ ) on shear stress at $1 \mathrm{H}$ and

360 flow parameters during storage time

\begin{tabular}{|c|c|c|c|c|c|c|}
\hline \multirow{2}{*}{$\begin{array}{l}\text { Viscoelasticity } \\
\text { (dynamic } \\
\text { testing) }\end{array}$} & \multirow[t]{2}{*}{ Units } & \multirow{2}{*}{$\begin{array}{c}\text { Storage } \\
\text { Time } \\
\text { Days }\end{array}$} & \multicolumn{4}{|c|}{ Kefir Samples } \\
\hline & & & K & $\mathrm{K}+\mathrm{IN}$ & $\mathrm{K}+\mathrm{MCP}$ & $\mathrm{K}+\mathrm{MWF}$ \\
\hline \multirow{5}{*}{$\mathrm{G}^{\prime}$} & \multirow{5}{*}{$\mathrm{Pa}$} & 1 & $122.3 \pm 1.4 \mathrm{aB}$ & $99.5 \pm 2.6 \mathrm{aA}$ & $109.9 \pm 12.4 \mathrm{aAB}$ & $119.4 \pm 6.5 \mathrm{aB}$ \\
\hline & & 7 & $140.5 \pm 2.9 \mathrm{bB}$ & $116.0 \pm 3.0 \mathrm{bcA}$ & $137.8 \pm 0.4 \mathrm{bB}$ & $162.6 \pm 10.6 \mathrm{cC}$ \\
\hline & & 14 & $143.4 \pm 11.2 \mathrm{abB}$ & $122.9 \pm 0.8 \mathrm{cA}$ & $173.1 \pm 13.4 \mathrm{cC}$ & $133.8 \pm 9.8 \mathrm{bB}$ \\
\hline & & 21 & $159.3 \pm 7.4 \mathrm{cB}$ & $148.7 \pm 9.6 \mathrm{cA}$ & $138.7 \pm 4.9 \mathrm{bAB}$ & $153.1 \pm 0.6 \mathrm{bcB}$ \\
\hline & & 28 & $121.6 \pm 6.1 \mathrm{aA}$ & $111.8 \pm 8.1 \mathrm{bA}$ & $152.4 \pm 4.3 \mathrm{bB}$ & $150.8 \pm 8.6 \mathrm{bcB}$ \\
\hline \multirow[t]{5}{*}{ G" } & \multirow[t]{5}{*}{$\mathrm{Pa}$} & 1 & $34.1 \pm 0.1 \mathrm{bB}$ & $27.3 \pm 0.6 \mathrm{aA}$ & $28.4 \pm 3.0 \mathrm{aA}$ & $32.1 \pm 1.7 \mathrm{aB}$ \\
\hline & & 7 & $34.6 \pm 0.6 \mathrm{bcB}$ & $28.2 \pm 0.8 \mathrm{aA}$ & $33.5 \pm 0.07 \mathrm{bB}$ & $39.2 \pm 2.4 \mathrm{eC}$ \\
\hline & & 14 & $35.0 \pm 2.5 \mathrm{bA}$ & $32.7 \pm 1.7 \mathrm{bA}$ & $42.8 \pm 3.3 \mathrm{cB}$ & $34.1 \pm 2.6 \mathrm{bcA}$ \\
\hline & & 21 & $37.4 \pm 1.6 \mathrm{cB}$ & $37.2 \pm 3.6 \mathrm{bA}$ & $33.1 \pm 0.8 \mathrm{bcA}$ & $35.2 \pm 1.0 \mathrm{de} A B$ \\
\hline & & 28 & $29.9 \pm 1.7 \mathrm{aA}$ & $28.1 \pm 2.6 \mathrm{aA}$ & $36.5 \pm 0.2 \mathrm{bB}$ & $34.3 \pm 1.5 \mathrm{abB}$ \\
\hline \multirow[t]{5}{*}{$\operatorname{Tg} \delta$} & & 1 & $0.290 \pm 0.002 c \mathrm{C}$ & $0.270 \pm 0.002 \mathrm{~dB}$ & $0.250 \pm 0.002 \mathrm{cA}$ & $0.270 \pm 0.002 \mathrm{cB}$ \\
\hline & & 7 & $0.250 \pm 0.001 \mathrm{aB}$ & $0.240 \pm 0.005 \mathrm{aA}$ & $0.240 \pm 0.001 \mathrm{bA}$ & $0.240 \pm 0.009 \mathrm{bA}$ \\
\hline & & 14 & $0.25 \pm 0.02 \mathrm{baAB}$ & $0.26 \pm 0.02 \mathrm{cB}$ & $0.250 \pm 0.002 \mathrm{cA}$ & $0.240 \pm 0.004 \mathrm{bA}$ \\
\hline & & 21 & $0.270 \pm 0.001 \mathrm{bC}$ & $0.250 \pm 0.008 \mathrm{bB}$ & $0.240 \pm 0.002 \mathrm{bA}$ & $0.240 \pm 0.003 \mathrm{bA}$ \\
\hline & & 28 & $0.250 \pm 0.001 \mathrm{aB}$ & $0.250 \pm 0.005 \mathrm{bB}$ & $0.230 \pm 0.001 \mathrm{aA}$ & $0.230 \pm 0.002 \mathrm{aA}$ \\
\hline \multirow{5}{*}{$\begin{array}{c}\text { Flow parameters } \\
\text { K }\end{array}$} & \multirow{5}{*}{$\mathrm{Pa} \mathrm{s}^{-1}$} & 1 & $10.8 \pm 0.2 \mathrm{aA}$ & $11.3 \pm 0.1 \mathrm{bA}$ & $14.7 \pm 1.6 \mathrm{aB}$ & $13.0 \pm 2 \mathrm{caAB}$ \\
\hline & & 7 & $12.48 \pm 0.08 \mathrm{bB}$ & $10.72 \pm 0.01 \mathrm{aA}$ & $14.7 \pm 0.9 \mathrm{abC}$ & $15.0 \pm 0.9 \mathrm{abC}$ \\
\hline & & 14 & $12.7 \pm 0.2 \mathrm{bcB}$ & $12.1 \pm 0.3 \mathrm{cA}$ & $16.9 \pm 0.2 \mathrm{bcD}$ & $13.1 \pm 0.3 \mathrm{abC}$ \\
\hline & & 21 & $12.7 \pm 0.2 \mathrm{cA}$ & $12.1 \pm 0.3 \mathrm{cA}$ & $16.9 \pm 0.2 \mathrm{bcB}$ & $13.1 \pm 0.3 \mathrm{abB}$ \\
\hline & & 28 & $13.0 \pm 0.1 \mathrm{cA}$ & $11.89 \pm 0.06 \mathrm{bcA}$ & $15.6 \pm 1.2 \mathrm{bB}$ & $16.7 \pm 0.2 \mathrm{bB}$ \\
\hline \multirow[t]{5}{*}{$\mathrm{n}$} & & 1 & $0.190 \pm 0.007 \mathrm{bC}$ & $0.173 \pm 0.004 \mathrm{bC}$ & $0.090 \pm 0.002 \mathrm{aA}$ & $0.13 \pm 0.02 \mathrm{aB}$ \\
\hline & & 7 & $0.216 \pm 0.003 \mathrm{dBC}$ & $0.222 \pm 0.004 \mathrm{dC}$ & $0.19 \pm 0.02 \mathrm{cAB}$ & $0.18 \pm 0.02 \mathrm{bA}$ \\
\hline & & 14 & $0.209 \pm 0.003 \mathrm{cC}$ & $0.180 \pm 0.004 \mathrm{bB}$ & $0.16 \pm 0.01 \mathrm{bA}$ & $0.19 \pm 0.09 \mathrm{bB}$ \\
\hline & & 21 & $0.213 \pm 0.0005 \mathrm{cdB}$ & $0.199 \pm 0.010 \mathrm{cB}$ & $0.173 \pm 0.009 \mathrm{bcA}$ & $0.178 \pm 0.005 \mathrm{bA}$ \\
\hline & & 28 & $0.183 \pm 0.003 \mathrm{aB}$ & $0.145 \pm 0.005 \mathrm{aB}$ & $0.15 \pm 0.01 \mathrm{bA}$ & $0.175 \pm 0.003 \mathrm{bA}$ \\
\hline \multirow{5}{*}{$\begin{array}{c}\text { Relative } \\
\text { Hysteresis }\end{array}$} & \multirow{5}{*}{$\mathrm{Pa} \mathrm{s}^{-1}$} & 1 & $12.2 \pm 0.7 \mathrm{aB}$ & $10.9 \pm 1.1 \mathrm{aA}$ & $14.4 \pm 0.1 \mathrm{aD}$ & $13.3 \pm 0.3 \mathrm{aC}$ \\
\hline & & 7 & $13.74 \pm 0.07 \mathrm{bcB}$ & $11.4 \pm 0.2 \mathrm{abA}$ & $15.6 \pm 1.3 \mathrm{abC}$ & $14.7 \pm 2.8 \mathrm{abC}$ \\
\hline & & 14 & $10.8 \pm 0.2 \mathrm{aA}$ & $13.6 \pm 0.3 \mathrm{cB}$ & $16.5 \pm 1.3 \mathrm{bcC}$ & $16.7 \pm 1.0 \mathrm{bC}$ \\
\hline & & 21 & $10.3 \pm 0.6 \mathrm{aA}$ & $12.5 \pm 1.6 \mathrm{bcB}$ & $17.2 \pm 0.3 \mathrm{bcC}$ & $16.9 \pm 0.7 \mathrm{bC}$ \\
\hline & & 28 & $13.8 \pm 0.1 \mathrm{aA}$ & $15.33 \pm 0.06 \mathrm{~dB}$ & $17.9 \pm 0.3 \mathrm{cC}$ & $19.8 \pm 0.7 \mathrm{cD}$ \\
\hline
\end{tabular}

361

362

${ }^{\mathrm{a}}$ Means $\pm \mathrm{SD}, \mathrm{n}=3$, the values of the same column by parameter with different tiny letters are significantly different and the values in the same row with different capital letters are significantly different $(\mathrm{P}<0.05)$. ${ }^{\mathrm{b}} \mathrm{K}$, Control kefir; $\mathrm{K}+\mathrm{MWF}$, kefir with mucilage of faba bean; $\mathrm{K}+\mathrm{MCP}$, kefir with chickpea mucilage, $\mathrm{K}+\mathrm{IN}$, and kefir with inulin, storage at $4{ }^{\circ} \mathrm{C}$ during 28 days; G': Dependence of storage modulus; G”: loss modulus. $\operatorname{Tg} \delta$ : loss angle $=\mathrm{G}^{\prime} / \mathrm{G}^{\prime} ; \mathrm{k}$ : consistency index, $\mathrm{Pa} \mathrm{s}^{-1} ; \mathrm{n}$ : flow behavior index, dimensionless. 
370 Table 3. Color parameter changes during cold storage

\begin{tabular}{|c|c|c|c|c|c|}
\hline \multirow[t]{4}{*}{ Color Parameters } & Storage & \multicolumn{4}{|c|}{ Kefir Samples } \\
\hline & Days & $\mathrm{K}$ & $\mathrm{K}+\mathrm{IN}$ & $\mathrm{K}+\mathrm{MCP}$ & $\mathrm{K}+\mathrm{MWF}$ \\
\hline & 1 & $91.00 \pm 0.08 \mathrm{aB}$ & $89.20 \pm 0.03 \mathrm{aA}$ & $91.00 \pm 0.01 \mathrm{aB}$ & $89.2 \pm 0.03 \mathrm{aA}$ \\
\hline & 7 & $91.2 \pm 0.1 \mathrm{bC}$ & $89.86 \pm 0.01 \mathrm{cB}$ & $91.23 \pm 0.02 b C$ & $89.5 \pm 0.2 \mathrm{bA}$ \\
\hline \multicolumn{6}{|l|}{$\mathrm{L}^{*}(\mathrm{D} 65)$} \\
\hline & 14 & $91.27 \pm 0.04 \mathrm{cC}$ & $89.72 \pm 0.01 \mathrm{bB}$ & $91.26 \pm 0.08 \mathrm{bC}$ & $89.43 \pm 0.07 \mathrm{bA}$ \\
\hline & 21 & $91.31 \pm 0.02 \mathrm{bcC}$ & $89.94 \pm 0.02 \mathrm{~dB}$ & $91.37 \pm 0.07 \mathrm{bC}$ & $89.6 \pm 0.2 \mathrm{abA}$ \\
\hline & 28 & $91.36 \pm 0.01 \mathrm{cC}$ & $89.84 \pm 0.01 \mathrm{cB}$ & $91.38 \pm 0.03 b C$ & $89.69 \pm 0.08 \mathrm{bA}$ \\
\hline \multirow{5}{*}{$a^{*}(D 65)$} & 1 & $-1.02 \pm 0.02 \mathrm{cB}$ & $-0.34 \pm 0.02 \mathrm{dA}$ & $-1.05 \pm 0.01 \mathrm{~dB}$ & $-0.01 \pm 0.009 c \mathrm{c}$ \\
\hline & 7 & $-1.18 \pm 0.02 \mathrm{aA}$ & $-0.68 \pm 0.01 \mathrm{aB}$ & $-1.18 \pm 0.01 \mathrm{aA}$ & $-0.17 \pm 0.04 a b C$ \\
\hline & 14 & $-1.11 \pm 0.01 \mathrm{bcA}$ & $-0.58 \pm 0.01 \mathrm{cB}$ & $-1.12 \pm 0.02 \mathrm{cA}$ & $-0.18 \pm 0.02 \mathrm{abC}$ \\
\hline & 21 & $-1.13 \pm 0.01 \mathrm{bcA}$ & $-0.66 \pm 0.01 \mathrm{abB}$ & $-1.16 \pm 0.01 \mathrm{abA}$ & $-0.14 \pm 0.04 \mathrm{bC}$ \\
\hline & 28 & $-1.16 \pm 0.03 \mathrm{aA}$ & $-0.65 \pm 0.01 \mathrm{bB}$ & $-1.17 \pm 0.01 \mathrm{aA}$ & $-0.20 \pm 0.08 \mathrm{aC}$ \\
\hline \multirow{5}{*}{$b^{*}(D 65)$} & 1 & $9.99 \pm 0.09 \mathrm{aA}$ & $12.02 \pm 0.02 \mathrm{eC}$ & $10.25 \pm 0.04 \mathrm{bB}$ & $10.23 \pm 0.02 \mathrm{cB}$ \\
\hline & 7 & $9.58 \pm 0.05 \mathrm{aA}$ & $10.82 \pm 0.01 \mathrm{cC}$ & $9.57 \pm 0.04 \mathrm{aA}$ & $9.8 \pm 0.1 \mathrm{abB}$ \\
\hline & 14 & $9.55 \pm 0.07 \mathrm{aA}$ & $10.93 \pm 0.01 \mathrm{~dB}$ & $9.7 \pm 0.2 \mathrm{aA}$ & $9.70 \pm 0.05 \mathrm{aA}$ \\
\hline & 21 & $9.55 \pm 0.05 \mathrm{aA}$ & $10.71 \pm 0.01 \mathrm{bD}$ & $9.72 \pm 0.01 \mathrm{aB}$ & $9.81 \pm 0.01 \mathrm{bC}$ \\
\hline & 28 & $9.49 \pm 0.02 \mathrm{aA}$ & $10.36 \pm 0.01 \mathrm{aB}$ & $9.72 \pm 0.01 \mathrm{aA}$ & $9.71 \pm 0.07 \mathrm{aA}$ \\
\hline
\end{tabular}

372 Kefir (K, control) supplemented with mucilage faba bean (K+MWF), chickpea mucilage (K+MCP)

373 and inulin $(\mathrm{K}+\mathrm{IN})$ during refrigerated storage $\left(4^{\circ} \mathrm{C}, 28\right.$ days). Lightness ( $\mathrm{L}^{*}=0$ black, $\mathrm{L}^{*}=100$ white),

$374 a^{*}\left(+a^{*}=\right.$ red, $-a^{*}=$ green $)$ and $b^{*}\left(+b^{*}=\right.$ yellow, $-b^{*}=$ blue $)$. Each value represents the Mean \pm Standard

375 Deviation, $n=3$, the values of the same column by parameter with different tiny letters are

376 significantly different and the values in the same row with different capital letters are

377 significantly different $(\mathrm{P}<0.05)$. 
Table 4. Sensory analysis of kefir

\begin{tabular}{lccccc}
\hline & \multicolumn{5}{c}{ Kefir samples } \\
\cline { 2 - 4 } & $\mathrm{K}$ & $\mathrm{K}+\mathrm{MCP}$ & $\mathrm{K}+\mathrm{MWF}$ & $F$ & $P$ \\
\hline Odour & $6.6 \mathrm{a}$ & $6.4 \mathrm{a}$ & $6.3 \mathrm{a}$ & 1.26 & 0.279 \\
Flavour & $6.1 \mathrm{a}$ & $5.1 \mathrm{~b}$ & $4.7 \mathrm{~b}$ & 18.66 & $<0.001$ \\
Texture & $5.7 \mathrm{a}$ & $5.3 \mathrm{a}$ & $5.6 \mathrm{a}$ & 1.52 & 0.22 \\
Overall acceptability & $5.9 \mathrm{a}$ & $5.0 \mathrm{~b}$ & $5.3 \mathrm{~b}$ & 7.68 & $<0.001$ \\
Purchase intention & $3.0 \mathrm{a}$ & $2.3 \mathrm{~b}$ & $2.6 \mathrm{~b}$ & 10.38 & $<0.001$ \\
\hline
\end{tabular}

381

382 Kefir (K, control) supplemented with mucilage faba bean (K+MWF), chickpea mucilage (K+MCP)

383 during refrigerated storage $\left(4{ }^{\circ} \mathrm{C}, 28\right.$ days). Acceptability (9-point hedonic scale) and purchase

384 intention (5-point scale) data. $F$ from one-way ANOVA (samples) and probability. Each value 385 represents (means, $\mathrm{n}=3$ ). Means in a same row with different letters are significantly different $386(p<0.001)$. 
Fig.1

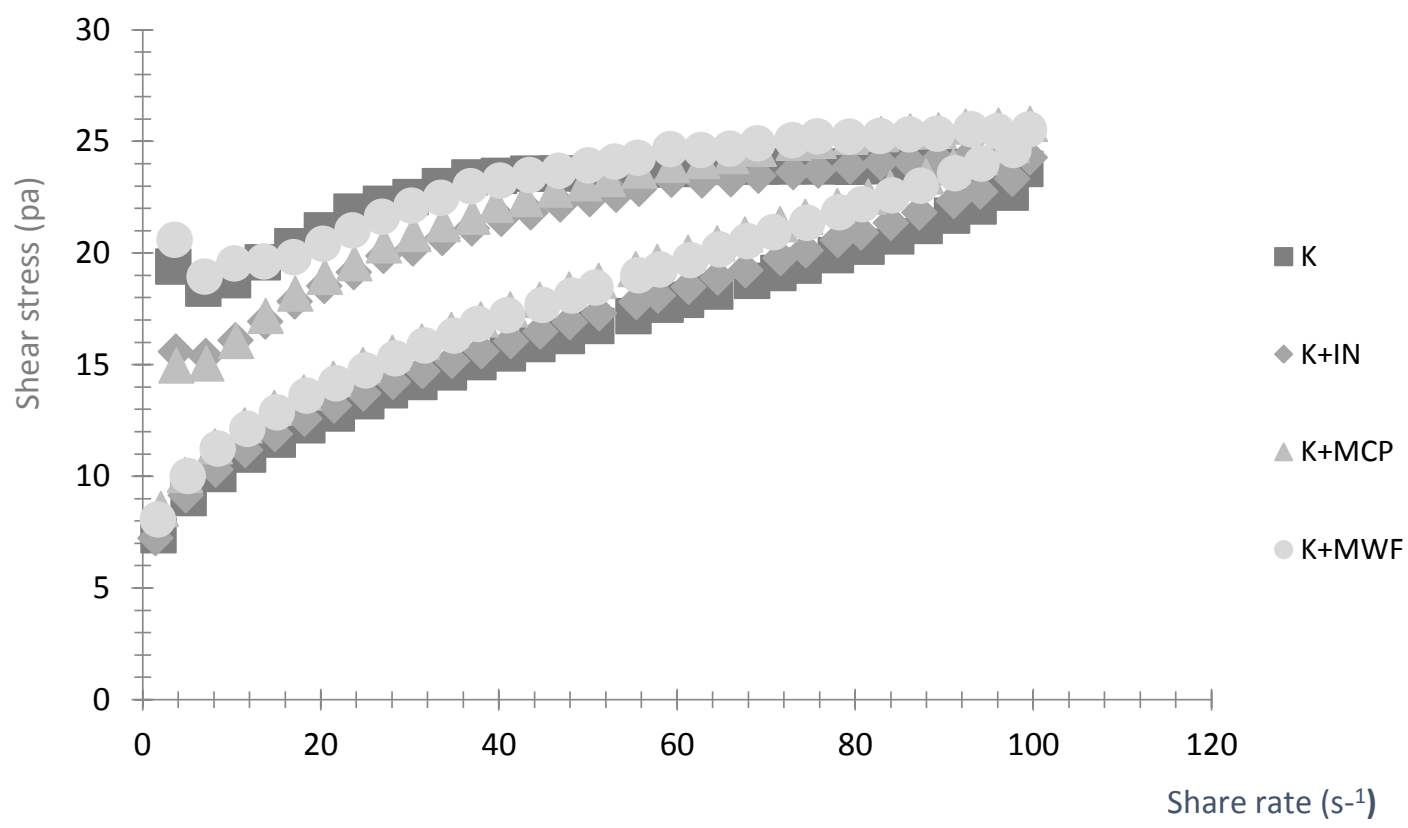


Fig. 2a

3

4

5

6

7

8

9

10

11

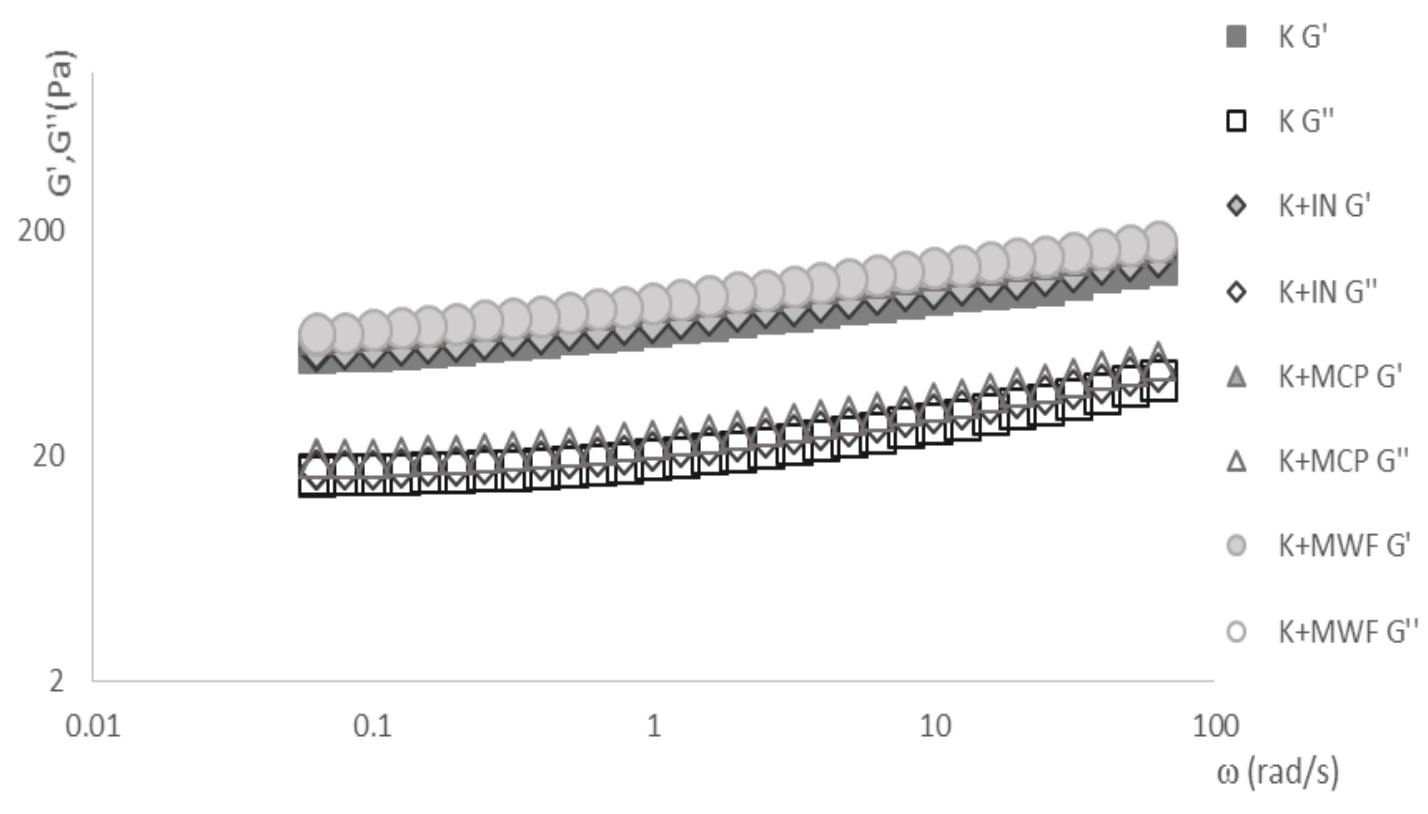

12 
Fig.2b

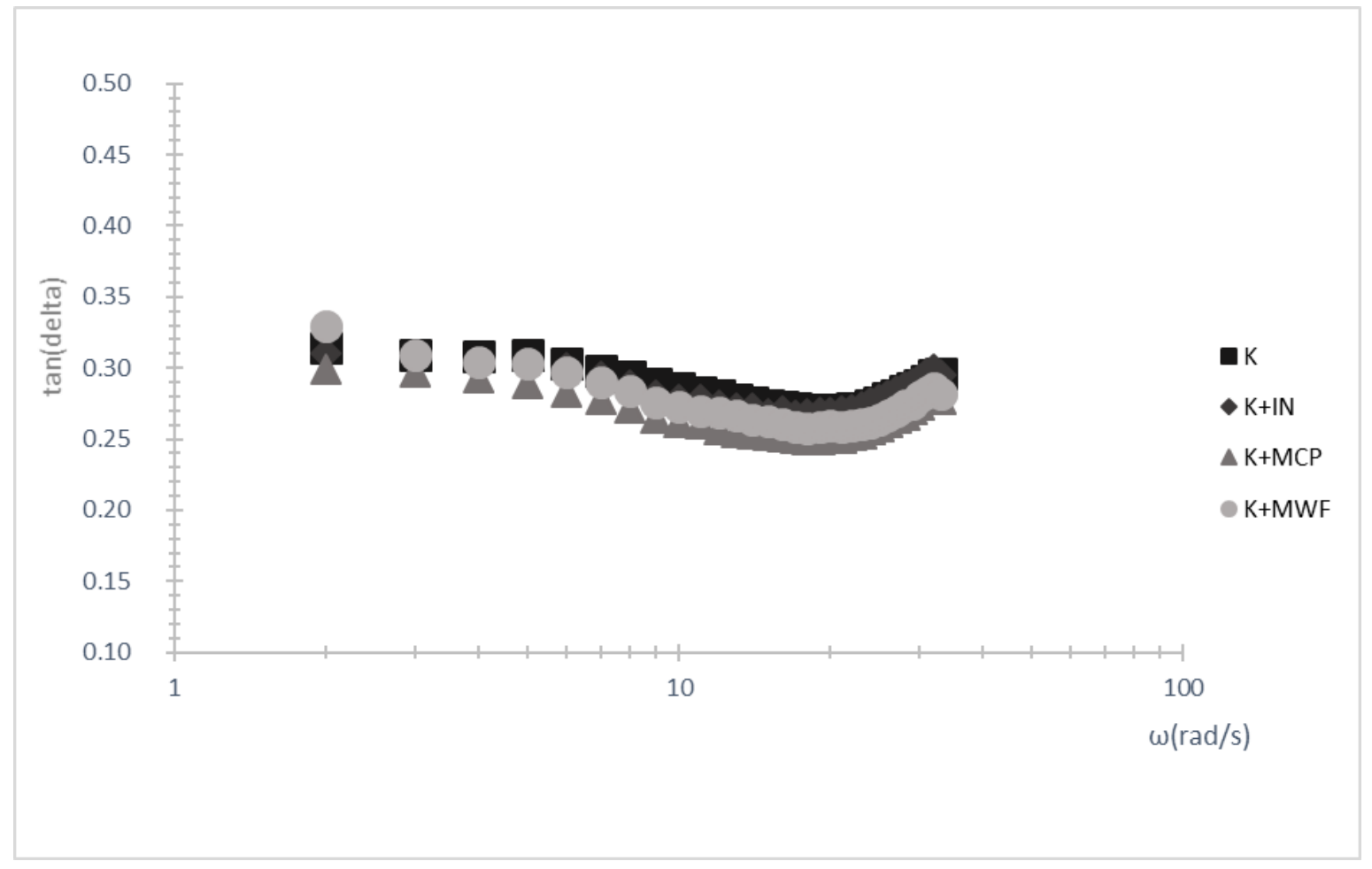

